\title{
Broodstock management and induced spawning of flounder Paralichthys orbignyanus (Valenciennes, 1839) under a closed recirculated system
}

\author{
Manejo de reproductores e inducción de desoves del lenguado Paralichthys orbignyanus \\ (Valenciennes, 1839) en sistema cerrado de recirculación
}

\author{
Gabriel A. Bambill ${ }^{1}$, Masakazu Oka ${ }^{2}$, Mariela Radonić ${ }^{1}$, Andrea V. López ${ }^{1}$, Mónica I. Müller ${ }^{1}$, \\ Juan J. Boccanfuso ${ }^{1}$ and Federico A. Bianca ${ }^{1}$ \\ ${ }^{1}$ Estación Experimental de Maricultura. Instituto Nacional de Investigación y Desarrollo Pesquero (INIDEP). Paseo Victoria \\ Ocampo No 1. B7602HSA Mar del Plata, Provincia de Buenos Aires, Argentina \\ ${ }^{2}$ Kamiura Station for Stock Enhancement. Fisheries Research Agency. 879-2602 Tuiura Kamiura Minamiamabe Oita, Japan \\ bambill@inidep.edu.ar
}

\begin{abstract}
The present study was conducted to determine the parameters regulating spawning performance of $P$. orbignyanus wild broodstock. The adaptation to captivity was successfully achieved with minimal stress levels. In three consecutive spawning seasons, the annual photothermal manipulation was not effective for the maturation and natural spawning of females although males were running. Females were HCG injected, releasing non fertilized eggs. Artificial fertilization was carried out after stripping the fish with a total production of 18,000 fertilized eggs in 2001 (egg diameter= $800 \pm 10 \mu \mathrm{m}), 55,300$ in 2002 (egg diameter $=850 \pm 12 \mu \mathrm{m})$ and 1,635,000 fertilized eggs in 2003 (egg diameter $818.4 \pm 30.08$ $\mu \mathrm{m}$, oil drop $98.1 \pm 2.96 \mu \mathrm{m}$ ). For the study of the ovulation time, females were hand-stripped every $48 \mathrm{~h}$ (female 1), $96 \mathrm{~h}$ (female 2) and $144 \mathrm{~h}$ (female 3), after being induced by hormones. No statistical differences were found for fertilization and hatching rates and SAI. This could be attributed to the small sample sizes, individual variation and/or stripping frequencies. Nevertheless, qualitative differences were evident. Although long-term studies are needed to confirm these observations, $96 \mathrm{~h}$ stripping frequency could be considered a good technique to obtain eggs and larvae experimentally. The estimated fecundity by this technique varied from 185,951 to 399,118 total eggs per $\mathrm{kg}$ of female.
\end{abstract}

Key words: Photothermal conditioning, stripping, HCG, Pisces
Resumen.- El presente estudio se realizó para determinar los parámetros que regulan la respuesta reproductiva de adultos salvajes de $P$. orbignyanus. La adaptación al cautiverio fue lograda exitosamente con niveles mínimos de estrés. Durante tres temporadas reproductivas consecutivas la manipulación fototermal no fue efectiva para la maduración y el desove natural de hembras, mientras que los machos estaban fluyentes. Las hembras fueron inyectadas con hormona gonadotrofina humana, liberando huevos no fertilizados. Los reproductores fueron sometidos a masaje abdominal y los huevos fueron fecundados artificialmente. Se obtuvieron 18,000 huevos fertilizados en 2001 (diámetro del huevo $=800 \pm 10 \mu \mathrm{m}$ ), 55.300 en 2002 (diámetro del huevo $=$ $850 \pm 12 \mu \mathrm{m}$ ) y 1.635 .000 en 2003 (diámetro del huevo= 818,4 $\pm 30,08 \mu \mathrm{m}$, diámetro de gota oleosa $=98,1 \pm 2,96 \mu \mathrm{m})$. Para el estudio del tiempo de ovulación, las hembras fueron sometidas a masaje abdominal cada $48 \mathrm{~h}$ (hembra 1), $96 \mathrm{~h}$ (hembra 2) y $144 \mathrm{~h}$ (hembra 3), posteriores a la inducción hormonal. No se observaron diferencias significativas para las tasas de fertilización y eclosión ni para el índice de actividad especifica, lo cual podría deberse al bajo tamaño muestral, variación individual y/o frecuencia de masaje abdominal. Sin embargo, hubo evidentes diferencias cualitativas. La frecuencia de masaje abdominal cada $96 \mathrm{~h}$ podría considerarse una técnica apropiada para asegurar la obtención de huevos y larvas experimentalmente. Estudios a largo plazo son necesarios para confirmar estas observaciones. La fecundidad estimada varió entre 185.951 y 399.118 huevos totales por $\mathrm{kg}$ de peso de hembra.

Palabras clave: Acondicionamiento fototermal, masaje abdominal, HCG, Pisces

\section{Introduction}

The Mariculture Experimental Station of INIDEP is in charge of the research and development of marine finfish aquaculture under closed recirculated water systems since 2001. Among the species studied, red porgy Pagrus pagrus (Linné, 1758) and flounder Paralichthys orbignyanus (Valenciennes, 1839) are 
considered the more promising (Radonić et al. $2005^{1}$ ). $P$. orbignyanus is one of the most valuable species of the genus Paralichthys due to its large size, flesh quality and increasing fishery demand. It is distributed from Río de Janeiro $\left(22^{\circ} \mathrm{S}\right)$, Brazil, to Punta Villarino $\left(41^{\circ}\right.$ S), Argentina. The species inhabits low salinity shallow waters such as Río de la Plata and Bahía Blanca estuaries, Mar Chiquita Lagoon and Samborombón Bay (Argentina). The ocular side has a dark brown colour with clear spots. Maximum size recorded for females is $103 \mathrm{~cm}$ whereas for males is $61 \mathrm{~cm}$ (Cousseau \& Perrotta 1998).

In 1994, the species of the genus Paralichthys of the Argentine Sea were identified and conveniently classified by Díaz de Astarloa (1994). Mellito da Silveira et al. (1995) studied the structure of the testis and the ovary of $P$. orbignyanus in the estuary of Patos Lagoon (Brazil) indicating some aspects of its reproductive strategy. López Cazorla (2005) recorded that wild $P$. orbignyanus spawning occurs from November to January in the estuary of Bahía Blanca. Macchi \& Díaz de Astarloa (1996) studied the reproductive cycle and fecundity of flounder Paralichthys patagonicus (Jordan, 1889) found in Argentine waters.

By the time the present studies were carried out (2001-2003), no information was available on broodstock management of $P$. orbignyanus under a closed recirculated water system, nor on photothermal control to induce spawning. Bambill et al. $(2000)^{2}$ acclimated and maintained in captivity a wild broodstock of the close species $P$. patagonicus subjected to photothermal manipulation and closed recirculated water system. These conditions allowed natural tank spawning of fertilized eggs. In a previous research, different responses of five $P$. orbignyanus females to LHRH-A cholesterol pellets implants (luteinising hormone releasing hormone analogue) were recorded. Two of them did not produce any ova at all after being stripped every $48 \mathrm{~h}$, whereas the other three

\footnotetext{
${ }^{1}$ Radonić M, GA Bambill, O Mazakazu, AV López, MI Müller \& JJ Boccanfuso. 2005. Broodstock management and induced spawning of wild black Argentine flounder Paralichthys orbignyanus in captivity. Aquaculture America 2005. 17-20 January 2005, New Orleans, USA.

${ }^{2}$ Bambill GA, FAR Pérez, MI Müller, AV López, EO Aristizóbal Abud, M Radonić \& AG Vega. 2000. Larvicultura del lenguado argentino Paralychthys patagonicus. IV de Jornadas de Ciencias del Mar. 11-15 de Septiembre 2000, Puerto Madryn, Argentina.
}

ovulated after 4 to 6 days. Total number of eggs produced was 21.813 , mean egg diameter was $814 \pm 77$ $\mu \mathrm{m}$ and mean hatching rate was $9.5 \pm 18.2 \%$ (range 0 56.2\%) (unpublished data). In 1997, Cerqueira et al. caught mature individuals from Conceição Lagoon (Brazil) that were maintained in $150 \mathrm{~L}$ tank with a daily water exchange of $20 \%$, at $16-18^{\circ} \mathrm{C}$. The collected eggs were fertilized after stripping HCG-induced females. These females ovulated 46 to $69 \mathrm{~h}$ after hormone induction. These data as well as those of P. olivaceus (Tsujigado et al. 1989, Kumagai 1999, Fushimi 2001, Kikuchi \& Takeda 2001) were used as models to initiate broodstock management of $P$. orbignyanus.

Abundant literature exists on broodstock management and culture technology of other flatfish of the genus Paralichthys such as $P$. dentatus and $P$. lethostigma in the United States of America (Daniels 2000, Lee \& Ostrowski 2001, Watanabe \& Carroll 2001) and P. adspersus and P. microps in Chile (Silva 2001). Other successfully cultured flatfish are turbot Scophthalmus maximus in the United Kingdom, France and Spain (Bromley et al. 1986, Devauchelle et al. 1988, McEvoy 1984, Forés et al. 1990, Rodriguez Alvariño \& Díaz Martínez 1990), and Atlantic halibut Hippoglossus hippoglossus in Norway and United Kingdom (Olsen et al. 1999, Shields et al. 1999).

The present study was conducted to determine the spawning performance of a wild broodstock of $P$. orbignyanus kept in captivity under a closed recirculated water system, and subjected to photothermal control since 1999. The results of three consecutive spawning seasons, 2001 to 2003, are presented in terms of number of eggs obtained by two techniques (natural spawning and hand-stripping), egg diameter, fertilization and hatching rates and larval tolerance to starvation. The optimum timing for stripping was also studied to determine the ovulatory rhythms and to estimate the fecundity of this species.

\section{Material and methods}

\section{Broodstock management}

The fish were captured by a bottom-net from 1998 to 2001 in Mar Chiquita Estuary and Samborombón Bay. Fish were examined at arrival at INIDEP and put in a quarantine tank for two weeks. One oxytetracycline bath per week $(50 \mathrm{ppm}, 1 \mathrm{~h})$ was applied to avoid bacterial diseases. After two weeks acclimation period, all fish 
were individually tagged (PIT taggs) before stocking in an indoor concrete tank ( $5 \mathrm{~m}$ diameter and $80 \mathrm{~cm}$ water depth). The recirculating seawater system $\left(12 \mathrm{~m}^{3} / \mathrm{h}, 5 \%\right.$ exchange/week) consisted on a settler, a foam skimmer, a biological filter, a Heating/Cooler system (automatic, titanium) and four UV lights (160.000 $\mu$ watts $\mathrm{x} \mathrm{seg} / \mathrm{cm}^{2}$; Bio Light S.A., Chile) (Fig. 1). The settler and the foam skimmer removed solid wastes. Effluent water was biofiltered for a biological conversion of ammonia to nitrate. Salinity ranged from 33 to $36 \mathrm{psu}$ and $\mathrm{pH}$ ranged from 7.30 to 8.40 .

Female body weight ranged from 894 to $4,398 \mathrm{~g}$ (mean $\pm \mathrm{SD}=2,571 \pm 1,200 \mathrm{~g}$ ) whereas male's varied from 1,068 to $1,948 \mathrm{~g}(1,528 \pm 348.6 \mathrm{~g})$. Total length recorded for females and males was $43.6-69.4 \mathrm{~cm}$ $(57.80 \pm 8.39 \mathrm{~cm})$ and 34.0 to $53.2 \mathrm{~cm}(49.8 \pm 3.81 \mathrm{~cm})$, respectively. Sex ratio used for stocking was 1: 0.7 that is ten females: seven males. Broodstock were fed by hand once a day to satiation using fresh squid (Illex argentinus), anchovy (Engraulis anchoita) and silverside (Odonthestes argentinensis).

Broodstock were induced to mature through the control of water temperature and photoperiod (Fig. 2). The spawning season was scheduled from January to April at $15 \pm 1{ }^{\circ} \mathrm{C}$ and photoperiod fixed at 16hL: $08 \mathrm{hD}$ (hours light: hours darkness). While males were running, final maturation and ovulation of females were achieved after $\mathrm{HCG}$ injection (Human Chorionic Gonadotropin, 1,000 IU/kg for females, Tiekoku Co. Ltd., Japan). Gonadal maturation in females was evaluated by canulation, and oocytes diameters were measured using an image analyzer (Nikon Profile Projector V-12B, Japan) and an electronic caliper (Absolute digimatic, Mitutoyo Corp., Japan). Females selected for hormone induction showed oocytes $\geq 500$ $\mu \mathrm{m}$ in diameter. In 2001 and 2002, eggs were stripped every $48 \mathrm{~h}$ and artificially fertilized (wet method, Bromage 1996a) with sperm of 2-3 running males.

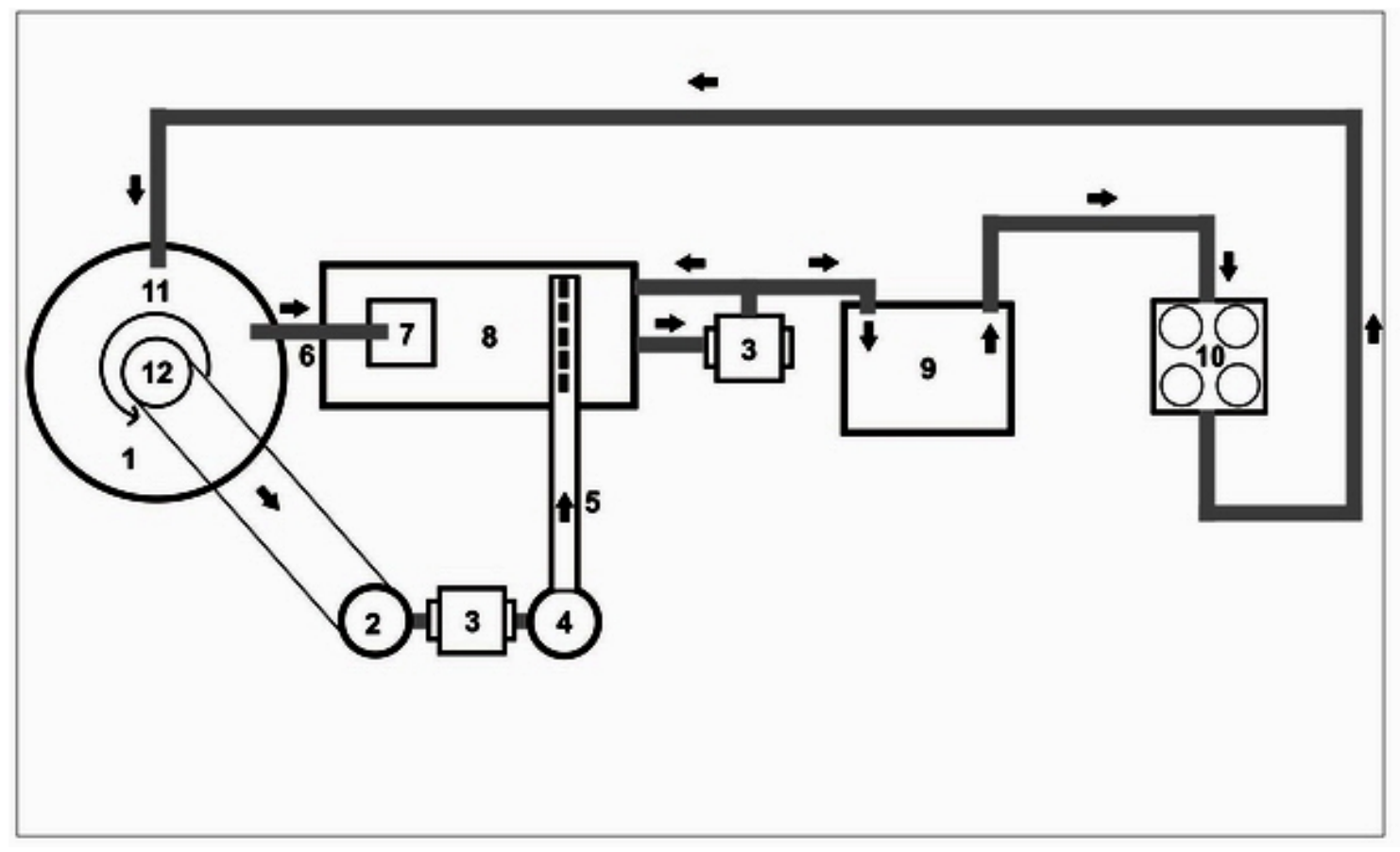

Figure 1

Recirculating water system used for $P$. orbignyanus broodstock. 1. Broodstock tank, 2. Settler, 3. Electromagnetic pump, 4. Foam skimmer, 5. Foam skimmer outlet, 6. Overflow, 7. Egg collector, 8. Biological filter, 9. Heating/Cooler system, 10. UV lights, 11. Tank inlet, 12. Water direction

Sistema de recirculación de agua para reproductores de $P$. orbignyanus. 1. Tanque de reproductores, 2. Decantador, 3. Bomba electromagnética, 4. Espumador, 5. Salida del espumador, 6. Salida por rebalse, 7. Colector de huevos, 8. Filtro biológico, 9. Intercambiador de calor/frío, 10. Lámparas ultravioleta, 11. Entrada de agua al tanque de reproductores, 12. Circulación del agua 


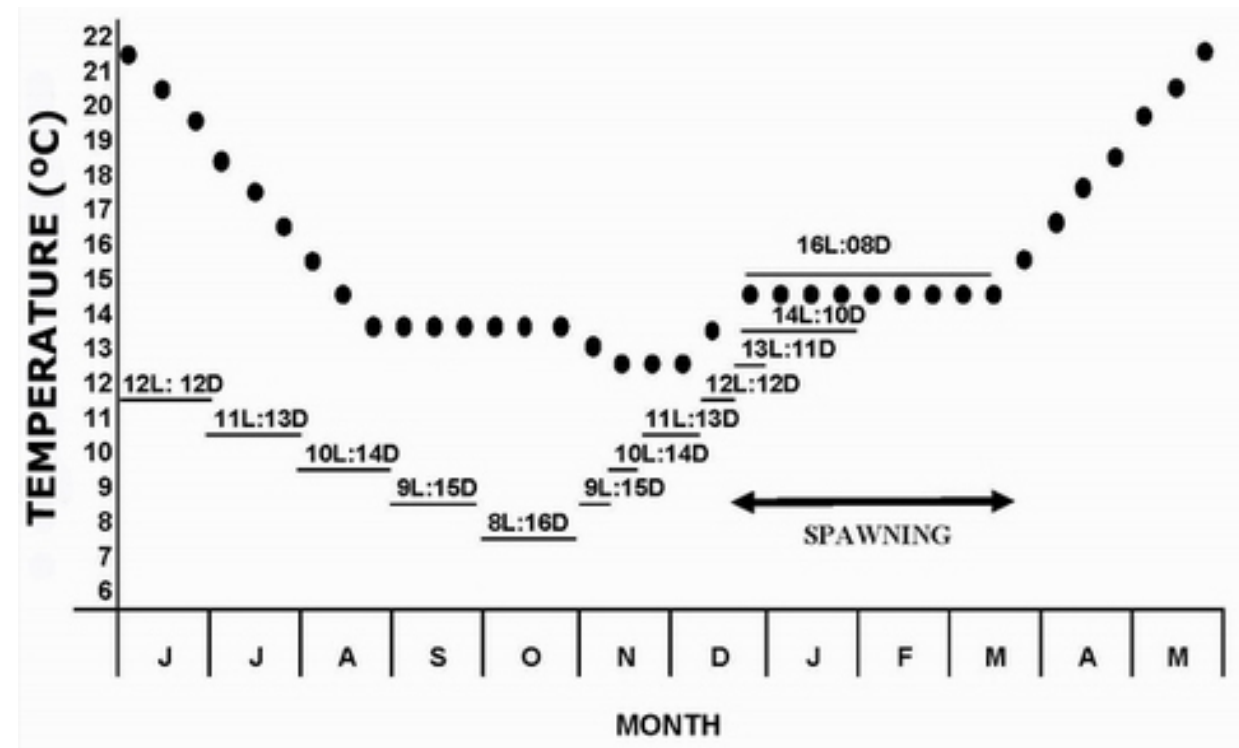

Figure 2

Temperature and photoperiod changes used for $P$. orbignyanus broodstock during 2001, 2002 and 2003 spawning seasons. Photoperiod expressed as number of hours of light:hours of darkness (L:D)

Cambios de temperatura y fotoperíodo aplicados a los reproductores de P. orbignyanus en las temporadas reproductivas 2001,2002 y 2003. Fotoperíodo expresado como número de horas luz: horas de oscuridad (L:D)

\section{Ovulation time}

In 2003, a study to estimate the precise timing for stripping was carried out. By 17 March, females were biopsied and only three presented oocytes $\geq 500 \mu \mathrm{m}$ in diameter, therefore they were HCG injected. These females were monitored after hormonal injection as follows: Female $1(59.7 \mathrm{~cm}$ and 3,405 g): every $48 \mathrm{~h}$; Female $2(60.4 \mathrm{~cm}$ and 3,744 g): every $96 \mathrm{~h}$; Female 3 $(69.4 \mathrm{~cm}$ and 4,091g): every $144 \mathrm{~h}$.

The eggs collected from each female were artificially fertilized with sperm of $2-3$ running males, and total fecundity (number of eggs per $\mathrm{kg}$ of female) estimated.

\section{Egg collection}

The egg net $(300 \mu \mathrm{m})$ suspended beneath the overflow outlet and inside the biological filter was daily checked to collect the eggs obtained from natural spawning. The eggs were washed and placed in graduated cylinders to separate buoyant and non buoyant. Buoyant layer of eggs contain both fertilized and non fertilized eggs. Fertilized eggs were considered as viable. Sinking eggs were considered non-viable (Aristizábal et al. 1997, Bromage 1996b). The two layers of eggs were separated using a fine mesh, their numbers estimated from three 1 $\mathrm{mL}$ sub-samples and the fertilization rate was recorded (FR). The diameter of the egg and the oil droplet was measured from a sub-sample of 30 eggs using an image analyzer (Nikon Profile Projector V-12B, Japan) and an electronic caliper (Absolute digimatic, Mitutoyo Corp., Japan). Diameters are presented as mean \pm SD. The embryonic stage and estimated spawning time were determined according to Oka \& Bambill (2003).

\section{Hatching rate and Specific Activity Index}

The quality of the different batches obtained in 2003 was evaluated according to the hatching rate (HR) and the Specific Activity Index (SAI) as described by Radonić et al. (2005) for Pagrus pagrus.

\section{Statistical analysis}

Data on fertilization and hatching rates and SAI obtained from the ovulation time study were statistically treated using the Kruskal-Wallis non-parametric test. 


\section{Results}

\section{Broodstock conditioning and natural spawning}

Running males and mature females showing a swollen abdomen were observed during the three spawning seasons using the photothermal conditions cited above.
However, no hydrated oocytes were observed by ovarian biopsy and stripping. Females induced by the use of HCG, spawned naturally non fertilized eggs during the three years. Total egg production obtained by natural spawning and stripping in spawning seasons 2001-2003 are presented in Table 1. Data of 2003 summarizes the egg production obtained from females 1,2 and 3 subjected to the study of the ovulation time.

Table 1

P. orbignyanus total egg production obtained by natural spawning and stripping in three spawning seasons. ED= Mean egg diameter; HR= Mean hatching rate; $\mathrm{NF}=$ Non fertilized eggs; $\mathrm{F}=$ Fertilized eggs $(\mathbf{1 0 0 \% )}$. Values in brackets are $\pm \mathrm{SD}$

Producción total de huevos de $P$. orbignyanus provenientes de desoves naturales y por masaje abdominal durante tres temporadas reproductivas. $\mathrm{ED}=$ Diámetro medio del huevo; $\mathrm{HR}=$ Tasa media de eclosión; $\mathrm{NF}=$ Huevos no fertilizados; $\mathrm{F}=\mathrm{Huevos}$ fertilizados $(100 \%)$. Valores entre paréntesis son $\pm \mathrm{DE}$

\begin{tabular}{|c|c|c|c|c|c|c|c|c|c|c|}
\hline \multirow[b]{2}{*}{ Month } & \multicolumn{4}{|c|}{$\begin{array}{l}\text { Natural Spawning } \\
\text { Buoyant eggs }\end{array}$} & \multicolumn{6}{|c|}{$\begin{array}{c}\text { Stripping } \\
\text { Buoyant eggs }\end{array}$} \\
\hline & Batches & $\begin{array}{c}\mathrm{Nr} \\
\left(\mathrm{x} 10^{3}\right)\end{array}$ & Type & $\begin{array}{l}\text { Total eggs } \\
\left(\mathrm{x} 10^{3}\right)\end{array}$ & Batches & $\begin{array}{c}\mathrm{Nr} \\
\left(\mathrm{x} 10^{3}\right)\end{array}$ & Type & $\begin{array}{c}\text { ED } \\
(\mu \mathrm{m})\end{array}$ & $\begin{array}{l}\mathrm{HR} \\
(\%)\end{array}$ & $\begin{array}{l}\text { Total eggs } \\
\left(\mathrm{x} 10^{3}\right)\end{array}$ \\
\hline Jan 2001 & 10 & 247.6 & $\mathrm{NF}$ & 3,848 & - & - & - & - & - & - \\
\hline Feb 2001 & 28 & 193.8 & $\mathrm{NF}$ & 1,235 & 3 & 18 & $\mathrm{~F}$ & $\begin{array}{c}800 \\
(10.0)\end{array}$ & $\begin{array}{c}36.1 \\
(13.03)\end{array}$ & 63.5 \\
\hline March 2001 & 10 & - & - & 69 & - & - & - & - & - & - \\
\hline $\begin{array}{l}2001 \\
\text { TOTAL }\end{array}$ & 48 & 441.4 & $\mathrm{NF}$ & 5,152 & 3 & 18 & $\mathrm{~F}$ & $\begin{array}{c}800 \\
(10.0)\end{array}$ & $\begin{array}{c}36.1 \\
(13.03)\end{array}$ & 63.5 \\
\hline Feb 2002 & 20 & - & - & 2,980 & 2 & 55.3 & $\mathrm{~F}$ & $\begin{array}{c}850 \\
(12.0)\end{array}$ & $\begin{array}{c}19.2 \\
(3.39)\end{array}$ & 116.5 \\
\hline March 2002 & 22 & - & - & 520 & - & - & - & - & - & - \\
\hline $\begin{array}{l}2002 \\
\text { TOTAL }\end{array}$ & 44 & - & - & 3,500 & 2 & 55.3 & $\mathrm{~F}$ & $\begin{array}{c}850 \\
(12.0)\end{array}$ & $\begin{array}{c}19.2 \\
(3.39)\end{array}$ & 116.5 \\
\hline March 2003 & 9 & 215 & $\mathrm{NF}$ & 907 & 12 & 1,385 & $\mathrm{~F}$ & $\begin{array}{c}816.9 \\
(32.55)\end{array}$ & $\begin{array}{c}9.2 \\
(11.01)\end{array}$ & 2,697 \\
\hline April 2003 & 16 & 192 & $\mathrm{NF}$ & 786 & 7 & 250 & $\mathrm{~F}$ & $\begin{array}{c}820.9 \\
(28.06)\end{array}$ & $\begin{array}{c}10 \\
(13.11)\end{array}$ & 556 \\
\hline $\begin{array}{l}2003 \\
\text { TOTAL }\end{array}$ & 25 & 407 & $\mathrm{NF}$ & 1,693 & 19 & 1,635 & $\mathrm{~F}$ & $\begin{array}{c}818.4 \\
(30.08)\end{array}$ & $\begin{array}{c}9.5 \\
(11.52)\end{array}$ & 3,253 \\
\hline
\end{tabular}




\section{Ovulation time and fecundity}

The observations lasted a month. Total number of eggs produced, percentage fertilized eggs, egg and oil droplet diameters and SAI recorded for all egg batches obtained per female are presented in Table 2. The mean oil drop diameter was $98.1 \pm 2.96 \mu \mathrm{m}$. FR and HR for females stripped at different frequencies are shown in Figs. 3 and 4 , respectively. The stripping procedure was stopped for female 1 after 16 days, since it showed injuries all over the body due to repetitive handling. FR average for female 1 was $60.2 \pm 33.1 \%$ (range 0.0 -
95.1\%). Female 2 had an average value of $43.0 \pm 18.0 \%$ (range 19.4-70.3\%). Average FR for female 3 was $36.8 \pm 16.9 \%$ (range $15.4-62.2 \%$ ). Average HR for females 1,2 and 3 were $1.9 \pm 2.41 \%$ (range $0.0-5.1 \%$ ), $20.5 \pm 14.79 \%$ (range $0.0-34.5 \%$ ) and $13.9 \pm 11.77 \%$ (range $0.0-30.4 \%$ ), respectively. No significant differences were found with the Kruskal-Wallis test for FR, HR and SAI $(P>0.05)$ for the three females. Female fecundity varied from 185,951 to 399,118 total eggs produced per $\mathrm{kg}$ and from 76,146 to 233,765 fertilized eggs produced per kg (Table 3 ).

Table 2

P. orbignyanus egg batches obtained from females 1, 2 and 3 stripped every 48, 96 and 144 h, respectively, after hormonal (HCG) induction on 17 March 2003. TE= Total number of eggs; FE= Number of fertilized eggs; ED= Egg diameter (mm); $\mathrm{OD}=$ Oil droplet diameter $(\mathrm{mm}) ; \mathrm{SAI}=$ Specific Activity Index; ND= No data available

Camadas de huevos de P. orbignyanus obtenidas de hembras 1, 2 y 3 (inyectadas con hormona HCG el 17 de marzo 2003) mediante masaje abdominal cada 48, 96 y 144 h, respectivamente. TE= Número total de huevos; FE= Número de huevos fertilizados; ED= Diámetro del huevo (mm); OD= Diámetro de la gota oleosa $(\mathrm{mm})$; SAI= Índice de actividad específica; $\mathrm{ND}=\mathrm{Datos}$ no disponibles

\begin{tabular}{|c|c|c|c|c|c|c|c|c|c|c|c|c|c|c|c|}
\hline \multirow[b]{2}{*}{$\begin{array}{c}\text { Date } \\
\text { Day-month }\end{array}$} & \multicolumn{5}{|c|}{ Female 1} & \multicolumn{5}{|c|}{ Female 2} & \multicolumn{5}{|c|}{ Female 3} \\
\hline & $\begin{array}{c}\mathrm{TE} \\
\left(\mathrm{x} 10^{3}\right)\end{array}$ & $\begin{array}{c}\mathrm{FE} \\
\left(\mathrm{x} 10^{3}\right)\end{array}$ & $\begin{array}{c}\mathrm{ED} \\
(\mu \mathrm{m})\end{array}$ & $\begin{array}{l}\mathrm{OD} \\
(\mu \mathrm{m})\end{array}$ & SAI & $\begin{array}{c}\mathrm{TE} \\
\left(\mathrm{x} 10^{3}\right)\end{array}$ & 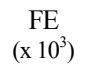 & $\begin{array}{c}\mathrm{ED} \\
(\mu \mathrm{m})\end{array}$ & $\begin{array}{l}\mathrm{OD} \\
(\mu \mathrm{m})\end{array}$ & SAI & $\begin{array}{c}\mathrm{TE} \\
\left(\mathrm{x} 10^{3}\right)\end{array}$ & $\begin{array}{c}\mathrm{FE} \\
\left(\mathrm{x} 10^{3}\right)\end{array}$ & $\begin{array}{c}\mathrm{ED} \\
(\mu \mathrm{m})\end{array}$ & $\begin{array}{c}\mathrm{OD} \\
(\mu \mathrm{m})\end{array}$ & SAI \\
\hline $19-3$ & 0 & 0 & - & - & - & & & & & & & & & & \\
\hline $21-3$ & 378 & 138 & 766 & ND & 1.4 & 584 & 330 & 811 & ND & - & & & & & \\
\hline $23-3$ & 243 & 82 & 762 & ND & - & & & & & & 3.4 & 1.2 & 832 & ND & 0.3 \\
\hline $25-3$ & 252 & 178 & 822 & ND & 13.5 & 170 & 33 & 801 & ND & 13.5 & & & & & \\
\hline $27-3$ & 90 & 78 & 839 & 94.9 & - & & & & & & & & & & \\
\hline $29-3$ & 258 & 196 & 858 & 94.7 & - & 147 & 60 & 801 & 100.5 & 19.9 & 354 & 142 & 833 & ND & 13.0 \\
\hline $31-3$ & 54 & 44,8 & 860 & 92.9 & 19.6 & & & & & & & & & & \\
\hline $2-4$ & 82 & 78 & 846 & 95.3 & - & 64 & 45 & 788 & 99.8 & 20.4 & & & & & \\
\hline $4-4$ & & & & & & & & & & & 164 & 102 & 851 & 99.4 & 20.0 \\
\hline $6-4$ & & & & & & 87 & 33 & 799 & 99.6 & 17.8 & & & & & \\
\hline \multicolumn{16}{|l|}{$8-4$} \\
\hline $10-4$ & & & & & & 82 & 27 & 792 & 100.4 & - & 189 & 59 & 849 & 100.2 & 5.5 \\
\hline \multicolumn{16}{|l|}{$12-4$} \\
\hline \multicolumn{16}{|l|}{$14-4$} \\
\hline $16-4$ & & & & & & & & & & & 52 & 8 & 821 & 101 & - \\
\hline Total & 1,357 & 794,8 & & & & 1,134 & 528 & & & & 762,4 & 312,2 & & & \\
\hline Mean & 169,6 & 99,4 & 828.3 & 94.5 & 11.5 & 189 & 88 & 791.3 & 100.1 & 17.9 & 152,5 & 62,4 & 837.2 & 100.2 & 9.7 \\
\hline SD & 130.7 & 66.6 & 34.3 & 1.1 & 9.3 & 197.8 & 119.1 & 13.0 & 0.4 & 3.1 & 136.4 & 60.5 & 12.6 & 0.8 & 8.6 \\
\hline
\end{tabular}

$\mathrm{TE}=$ Total number of eggs

$\mathrm{OD}=$ Diameter of the oil droplet $(\mathrm{mm})$
$\mathrm{FE}=$ Number of fertilized eggs

$\mathrm{SAI}=$ Specific Activity Index
$\mathrm{ED}=$ Egg diameter $(\mathrm{mm})$

$\mathrm{ND}=$ No data available 


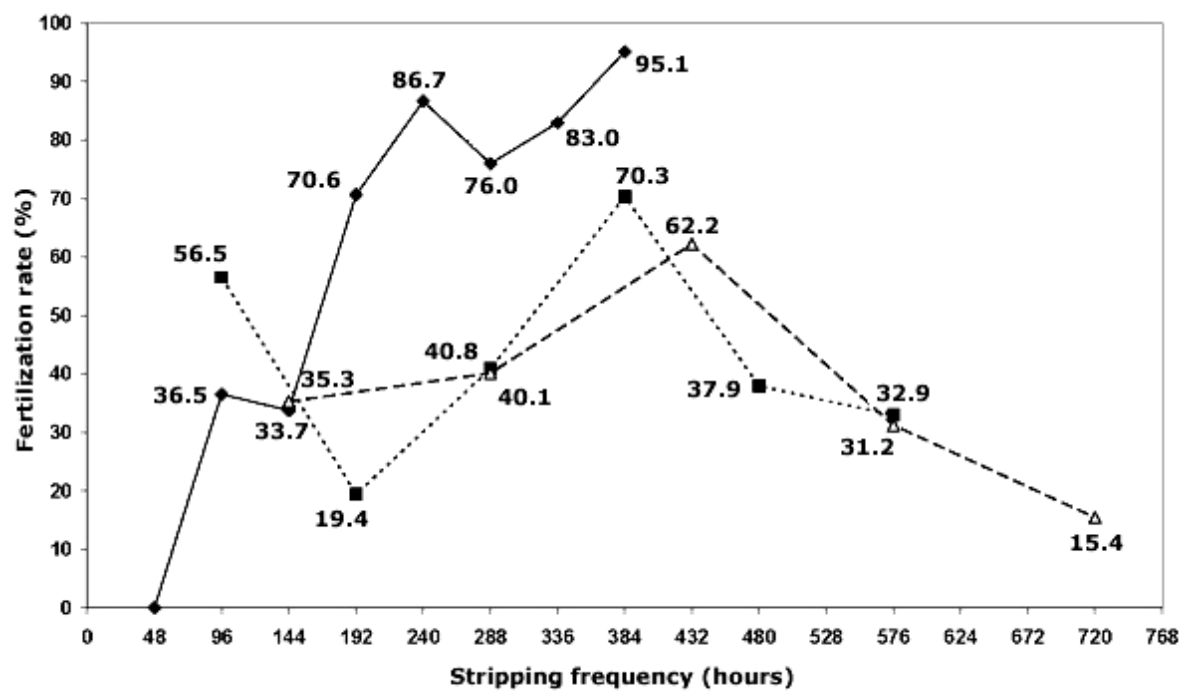

$\multimap$ Female 1 ......Female $2-\Delta$-Female 3

Figure 3

Fertilization rates of $P$. orbignyanus eggs obtained from females 1,2 and 3 stripped every 48,96 and $144 \mathrm{~h}$ after hormonal (HCG) injection

Tasas de fertilización de $P$. orbignyanus obtenidas para hembras 1, 2 y 3 sometidas a masaje abdominal cada 48, 96 y 144 h después de ser inyectadas con hormona HCG

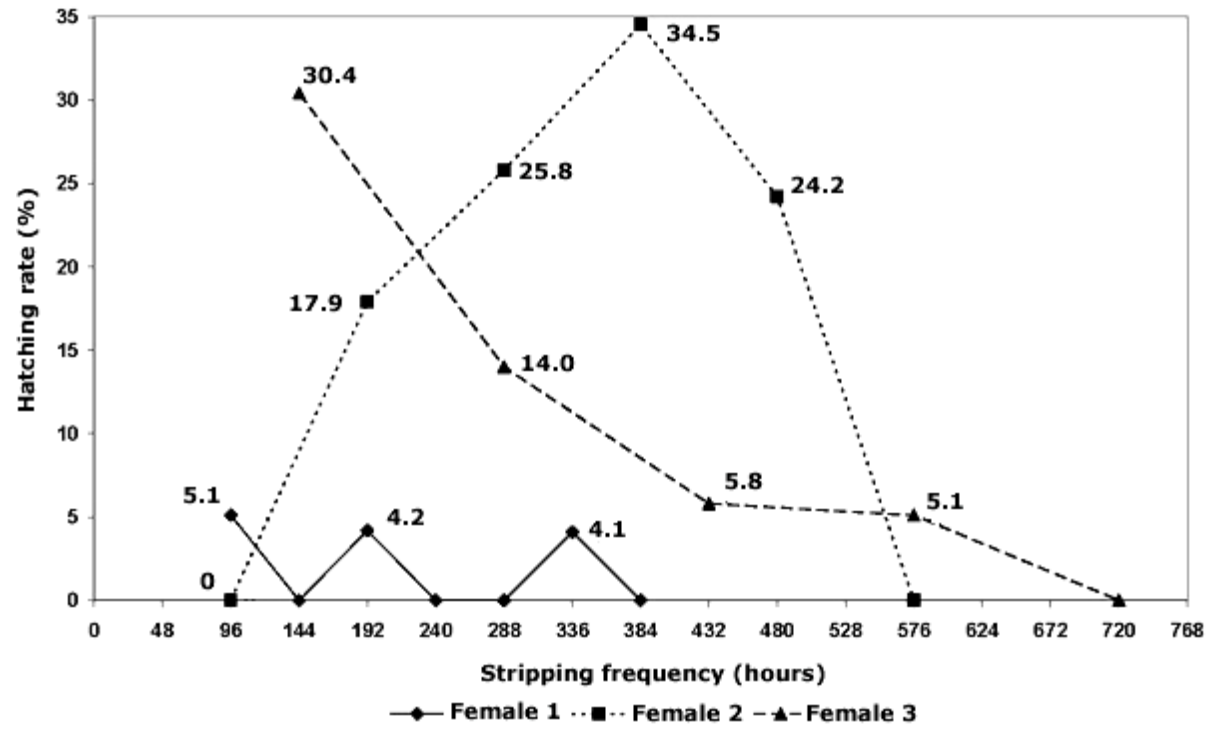

Figure 4

Hatching rates of $P$. orbignyanus obtained for females 1, 2 and 3 stripped every 48, 96 and $144 \mathrm{~h}$

Tasas de eclosión de P. orbignyanus obtenidas para las hembras 1, 2 y 3 sometidas a masaje abdominal cada 48, 96 y $144 \mathrm{~h}$ 


\section{Table 3}

Fecundity of $P$. orbignyanus expressed as total number of eggs per $\mathrm{kg}$ of female $(\mathrm{TE} / \mathrm{kg})$ and as fertilized eggs per $\mathrm{kg}$ of female (FE/kg), for females 1, 2, and 3, subjected to different stripping frequencies $(48,96$ and $144 \mathrm{~h})$. $\mathrm{TE}=$ Total eggs; $\mathbf{F E}=$ Fertilized eggs

Fecundidad de $P$. orbignyanus expresada como número total de huevos por $\mathrm{kg}$ de hembra (TE/kg) y como huevos fertilizados por $\mathrm{kg}$ de hembra (FE/kg), para hembras 1,2 y 3 sometidas a diferentes frecuencias de masaje abdominal (48, 96 y 144 h). TE= Huevos totales; FE= Huevos fertilizados

\begin{tabular}{ccc}
\hline \multirow{2}{*}{ Female } & \multicolumn{2}{c}{ Fecundity } \\
& TE/kg & FE $/ \mathrm{kg}$ \\
\hline 1 & 399,118 & 233,765 \\
2 & 306,486 & 142,703 \\
3 & 185,951 & 76,146 \\
\hline
\end{tabular}

\section{Discussion}

Many factors such as tank dimension, light intensity, nutritional status and husbandry of broodfish have been proved to greatly influence the reproductive behaviour of the fish and the production of eggs both in quality and in quantity (Furuita et al. 2000, Smith \& Denson 2000, Izquierdo et al. 2001, Schreck et al. 2001). During the years of this study, the adaptation to captivity was successfully achieved with minimal stress evidenced by the active feeding of Paralichthys orbignyanus broodstock and the absence of mortality and/or diseases. Management, husbandry conditions and water quality were efficient for the broodfish welfare. Smith \& Denson (2000) indicated high feeding rate as an index of adaptation of $P$. lethostigma to captive conditions. Robaldo (2003) reported 64\% mortality over a 6.5-month period of keeping $P$. orbignyanus broodfish in captivity, due to starvation and the appearance of the dinoflagellate parasite Amyloodinium cf. ocelatum (Abreu et al. 2005).

In this study, the annual photothermal manipulation was not as effective as expected for the maturation and natural spawning of wild female broodstock of $P$. orbignyanus in captivity, although it seemed to be effective for males. Unfertilized eggs were spontaneously released only if females were previously induced by the use of hormones. In species of the same genus, such as $P$. dentatus and $P$. lethostigma, variable fertility success has been attributed to low participation of males in the spawning events (Smith et al. 1999, Smith \& Denson 2000, Watanabe \& Carroll 2001). Similarly, in $P$. orbignyanus no courtship and spawning behaviour could be observed during three spawning seasons. Moreover, artificial fertilization was only achieved when the sperm of 2-3 running males was used, due to the low milt volume available per fish. According to Robaldo (2003), wild P. orbignyanus males kept under captive conditions were always running with good sperm quality and quantity. The absence of fertilized eggs by natural spawning could be attributed to inadequate water spawning temperature and sex ratio. The water temperature variation from 13 to $15^{\circ} \mathrm{C}$ would not induce ovulation and oviposition of females, and a sex ratio of 10 females: 7 males might have not favoured courtship. Robaldo (2003) suggested that a water temperature gradient of $6-7^{\circ} \mathrm{C}$ along the photothermal induction period would be appropriate to induce $P$. orbignyanus maturation. Some authors have recommended a sex ratio of 1-2 males: 1 female for Paralichthys reproduction, although the optimal ratio has not been determined yet (Kumagai 1999, Smith et al. 1999, Watanabe \& Carroll 2001).

Regarding the ovulation study, no statistical differences found for FR, HR and SAI could be attributed to the small sample sizes (one female/treatment, with no replication), individual variation and/or stripping frequencies. Nevertheless, qualitative differences were evident for the parameters mentioned above. Female stripped every $48 \mathrm{~h}$ showed increasing FRs values, HRs less than 5\% (linear trend) and poor health condition. FRs for females stripped every 96 and $144 \mathrm{~h}$ fluctuated over time, although HRs for the former showed a parabolic trend, and for the latter a decreasing tendency. Moreover, larvae obtained from the $96 \mathrm{~h}$ frequency showed more tolerance to starvation and activity. Although long-term studies are needed to confirm these observations, $96 \mathrm{~h}$ stripping frequency could be considered a good technique to obtain eggs and larvae experimentally. Robaldo (2003), keeping $P$. orbignyanus females at $26^{\circ} \mathrm{C}$ water temperature, reported female ovulation within 1 to 2 days after $\mathrm{HCG}$ induction.

Female fecundity is a valuable parameter to estimate the number of available eggs per spawning season. Macchi \& Díaz de Astarloa (1996) reported that Paralichthys patagonicus is a batch spawner with an estimated fecundity ranging from 20,000 to 160,000 hydrated oocytes in females of $42-53 \mathrm{~cm}$ total 
length. Cerqueira et al. (1997) presented preliminary results on HCG induction and stripping of $P$. orbignyanus wild mature adults (4 males and 4 females). Two females responded to hormone treatment yielding fertilized eggs by stripping and unfertilized eggs by natural spawning (one natural spawn per female). Females weighing $1.78 \mathrm{~kg}$ and $2.86 \mathrm{~kg}$ showed a fecundity of 224,000 and 280,000 eggs $/ \mathrm{kg}$, respectively. In the present study, female mean weight was over $3 \mathrm{~kg}$. All the females used for stripping produced higher number of eggs per $\mathrm{kg}$ than the values indicated by Cerqueira et al. (1997). The different fecundities recorded are not contradictory considering that broodstock size, age and genotype, as well as the daily and seasonal feeding rates can influence the number of eggs produced (Bromage 1996b). In the case of $P$. olivaceus, females weighing 4-5 $\mathrm{kg}$ and measuring $80 \mathrm{~cm}$ in length have an estimated fecundity of 200,0001,000,000 eggs (Kafuku et al. 1987).

Cerqueira et al. (1997) and Robaldo (2003) recorded egg diameters of 790 and $820 \mu \mathrm{m}$, and oil droplet diameters of 116 and $117 \mu \mathrm{m}$, respectively. The values presented in this study were similar being $818.4 \pm 30.08$ $\mu \mathrm{m}$ and $98.1 \pm 2.96 \mu \mathrm{m}$, respectively. Broodstock size, husbandry conditions, quality and quantity of food also influence egg dimensions as stated by Bromage (1996). In species of the same genus such as $P$. olivaceus the size of the egg and the oil droplet ranged from 820 to $960 \mu \mathrm{m}$ and 130 to $180 \mu \mathrm{m}$, respectively (Kafuku et al. 1987).

In summary, this work describes the management and conditioning of flounder Paralichthys orbignyanus for use as broodstock. The closed recirculated water system is effective for the long-term maintenance and welfare of captive fish. This system minimizes the outbreak of diseases and its application is increasing worldwide to reduce water pollution (Timmons et al. 2002). The Argentine coasts are widely opened not allowing the installation of cages or pens. Therefore, baseland farms with recirculated water systems are the only possibility for the development of marine finfish aquaculture. Timing and frequency of hand stripping are presented. Several parameters of the egg morphology such as egg and oil droplet diameters as well as fecundity, hatching rates and larval tolerance to starvation are reported. Further researches are needed focussed on the appropriate photothermal cycle to induce natural spawnings based on natural environmental conditions found in Argentine waters, sex ratio, reproductive biology, and rate of replacement of older fish by newly caught fish.

\section{Acknowledgments}

The Research Group of INIDEP would like to express their deepest gratitude to the Overseas Fisheries Cooperation Foundation (OFCF) of Japan for the donation of the Mariculture Experimental Station and their technical support since 2000. Lic. Daniel Hernández contributed with the statistical analysis. Dr. Alicia Estévez (IRTA, Spain), Dr. Bill Roy (Stirling University, Scotland) and Dr. Patrick Carroll (University of North Carolina, USA) have reviewed the manuscript. Dr. Ricardo B. Robaldo (University of Pelotas, Brazil) kindly sent us his PhD Thesis. We thank the anonymous referees for their suggestions. INIDEP Contribution $\mathrm{N}^{\mathrm{o}} 1338$.

\section{Literature cited}

Abreu P, RB Robaldo, C Odebrecht, LA Sampaio \& A Bianchini. 2005. Recurrent amyloodiniosis on broodstock of the Brazilian flounder Paralichthys orbignyanus: Dinospore monitoring and prophylactic measures. Journal of the World Aquaculture Society 36: 42-50.

Aristizábal EO, MI Müller, GA Bambill, AV López, M Sabatini, M Costagliola, S Incorvaia, A Vega, JC Carrizo \& E Manca. 1997. Producción de alimento vivo y cría de besugo. Período 1995-1996. Informe Técnico Interno INIDEP 83, $92 \mathrm{pp}$.

Bromage NR 1996a. Propagation and stock improvement. In: Sheperd J \& N Bromage (eds), Intensive fish farming: 103-150. Blackwell Science Ltd., Oxford, UK.

Bromage NR 1996b. Broodstock management and seed quality-General considerations. In: Bromage NR \& RJ Roberts (eds), Broodstock management and egg and larval quality: 1-24. Blackwell Science Ltd., Oxford, UK.

Bromley PJ, PA Sykes \& BR Howell. 1986. Egg production of turbot (Scophthalmus maximus L.) spawning in tank conditions. Aquaculture 53: 287-293.

Cerqueira VR, R Mioso, JAG Macchiavello \& AM Bruegger. 1997. Ensaios de indução de desova do linguado (Paralichthys orbignyanus Valenciennes, 1839). Boletim do Instituto de Pesca Sao Paulo 24: 247-254. 
Cousseau MB \& RG Perrotta. 1998. Peces marinos de Argentina. Biología, distribución, pesca, pp. 142-143. Instituto Nacional de Investigación y Desarrollo Pesquero. Secretaría de Agricultura, Ganadería, Pesca y Alimentación. Mar del Plata, Argentina.

Daniels HV. 2000. Species Profile, Southern Flounder. Southern Regional Aquaculture Center Publication 726: 14.

Díaz de Astarloa GM. 1994. Las especies del género Paralichthys (Pisces, Paralichthydae) del mar Argentino. Morfología y sistemática. Tesis Doctoral. Facultad de Ciencias Exactas y Naturales, Universidad Nacional de Mar del Plata, Argentina, 194 pp.

Devauchelle N, JC Alexandre, N Le Corre \& Y Letty. 1988. Spawning of turbot (Scophthalmus maximus L.) in captivity. Aquaculture 69: 159-184.

Forés R, J Iglesias, M Olmedo, FJ Sánchez \& JB Peleteiro. 1990. Induction of spawning in turbot (Scophthalmus maximus L.) by a sudden change in the photoperiod. Aquacultural Engineering 9: 357-366.

Furuita H, H Tanaka, T Yamamoto, M Shiraishi \& M Takeuchi. 2000. Effects of $n-3$ HUFA levels in broodstock diet on the reproductive performance and egg and larval quality of the Japanese flounder, Paralichthys olivaceus. Aquaculture 187: 387-398.

Fushimi H. 2001. Production of juvenile marine finfish for stock enhancement in Japan. Aquaculture 200: 33-53.

Izquierdo MS, H Fernández-Palacios \& AGJ Tacon. 2001. Effect of broodstock nutrition on reproductive performance of fish. Aquaculture 197: 25-42.

Kafuku T, H Ikenoue \& T Sakamoto. 1987. Aquaculture Organisms of the World. Kanagawa International Fisheries Training Centre, Japan. Japan International Cooperation Agency (JICA): 116-117.

Kikuchi K \& S Takeda. 2001. Present status of research and production of Japanese flounder Paralichthys olivaceus in Japan. Journal of Applied Aquaculture 11: 165-175.

Kumagai A. 1999. Broodstock management and egg collection of Japanese flounder. Hakatajima Station, Annual Report of JASFA: 37-40 (In Japanese).

Lee CS \& AC Ostrowski. 2001. Current status of marine finfish larviculture in the United States. Aquaculture 200: 89-109.
López Cazorla A. 2005. On the age and growth of flounder Paralichthys orbignyanus (Jenyns, 1842) in Bahia Blanca Estuary, Argentina. Hydrobiologia 537: 81-87.

Macchi GJ \& JD Díaz de Astarloa. 1996. Ciclo reproductivo y fecundidad del lenguado, Paralichthys patagonicus Jordan, en Jordan \& Goss 1889. Revista de Investigación y Desarrollo Pesquero 10: 73-83.

McEvoy LA. 1984. Ovulatory rythms and over-ripening of eggs in cultivated turbot Scophthalmus maximus L. Journal of Fish Biology 24: 437-448.

Mellito da Silveira MP, JCB Cousin \& M Haimovici. 1995. Estructura ovárica e testicular do linguado Paralichthys orbignyanus (Valenciennes, 1839). Atlântica 17: 135-152 (In Portuguese).

Oka M \& GA Bambill. 2003. Egg development of lenguado Paralichthys orbignyanus. In: Oka, M (ed), Technological development of seed production of besugo and lenguado in Argentine Republic. Internal Report (Jan. 2000-Aug. 2003): 37-41. Overseas Fishery Cooperation Foundation (OFCF)- Instituto Nacional de Investigación y Desarrollo Pesquero (INIDEP).

Olsen W, J Evjemo \& A Olsen. 1999. Status of the cultivation technology for production of Atlantic halibut (Hippoglossus hippoglossus) juveniles in Norway/Europe. Aquaculture 176: 3-13.

Radonić M, AV López, M Oka \& EO Aristizábal. 2005. Effect of the incubation temperature on the embryonic development and hatching time of eggs of the red porgy Pagrus pagrus (Linné, 1758) (Pisces: Sparidae). Revista de Biología Marina y Oceanografía 40(2): 91-99.

Robaldo, RB. 2003. Estudo comparativo da reprodução do linguado Paralichthys orbignyanus (Valenciennes, 1839) no ambiente e em cativeiro. Tese de Doutorado. Fundação Federal do Rio Grande, Brasil, 190 pp.

Rodríguez Alvariño M \& O Díaz Martínez. 1990. Producción de alevines de rodaballo (Scophthalmus maximus). Hojas Divulgadoras 3/90, 16 pp. Ministerio de Agricultura, Pesca y Alimentación, España.

Schreck CB, W Contreras-Sanchez \& MS Fitzpatrick. 2001. Effects of stress on fish reproduction, gamete quality, and progeny. Aquaculture 197: 3-24.

Shields R, B Gara \& M Gillespie. 1999. A UK perspective on intensive hatchery rearing methods for Atlantic halibut (Hippoglossus hippoglossus L.). Aquaculture 176: 15-25. 
Silva A. 2001. Advance in the culture research of small-eye flounder, Paralichthys microps, and Chilean flounder, $P$. adspersus, in Chile. Journal of Applied Aquaculture 11: 147-164.

Smith TIJ, DC McVey, WE Jenkins, MR Denson, LD Heyward, CV Sullivan \& DL Berlinsky. 1999. Broodstock management and spawning of southern flounder, Paralichthys lethostigma. Aquaculture 176: 8799.

Smith TIJ \& MR Denson. 2000. Controlled spawning of southern flounder Paralichthys lethostigma: Issues and Progress. Proceedings of the Twenty-Eight US-Japan Natural Resources, Technical Report 28: 97-108.
Timmons MB, JM Ebeling, FW Wheaton, ST Summerfelt \& BJ Vinci. 2002. Recirculating aquaculture systems, 747 pp. Northeastern Regional Aquaculture Center, Publication 01-002.

Tsujigado A, T Yamakawa, H Matsuda \& $\mathbf{N}$ Kamiya. 1989. Advanced spawning of the flounder Paralichthys olivaceus in an indoor tank with combined manipulation of water temperature and photoperiod. International Journal of Aquatic Fisheries Technology 1: 351-356.

Watanabe WO \& PM Carroll. 2001. Progress in controlled breeding of summer flounder, Paralichthys dentatus, and southern flounder, P. lethostigma. Journal of Applied Aquaculture 11: 89-111.

Recibido el 2 de agosto de 2005 y aceptado el 26 de enero de 2006 